\title{
Technical Progress and Development Trend of Electric Vehicles
}

\author{
Hongwei Zhang \\ Guangzhou Vocational College of Technology \& Business, Guangdong \\ Guangzhou, 511442
}

\begin{abstract}
In recent years, China has achieved initial results in electric vehicle research and development, but there are also some problems in the development of electric vehicles with zero emissions and energy-saving. This paper analyzes the latest development of electric vehicles in China to find out the problems and shortcomings, and make a scientific prediction for its development trend. Vigorously develop electric vehicles is to ensure Chinese energy security and it is an important choice for sustainable development.
\end{abstract}

Keywords: technical progress, development trend, electric vehicles

\section{Introduction}

The 1970s, after the world's three oil crisis, the multinational auto companies have started to develop various types of electric vehicles. China has invested a lot of manpower, material and financial resources in the research and development of electric vehicles, and has made a series of achievements in scientific research. However, up to now, China has made great achievements in the research and development of electric vehicle projects in the past years. The scientific research can really be transformed into products, and to achieve industrial production of the project is not much. Foreign large car companies than in China to invest more money and manpower, has been put into mass production of electric car products are also very few. However, with the global energy crisis deepening, the depletion of oil resources and air pollution, increasing the risk of rising global temperatures, governments and auto companies generally recognized that energy 
conservation and emission reduction is the main direction of the future development of automotive technology, the development of electric vehicles Will be the best way to solve these two technical difficulties.

\section{The Development History and Current Status of Electric Vehicles}

The electric vehicle is the fusion of the first two technologies, the "electrification" and the "car", among the 20 greatest engineering achievements of the 20th century. It is not the new idea of contemporary people, its idea and development are earlier than fuel vehicles, But the performance as fuel vehicles, to research and development work was stagnant. 20 century, 70 years of energy crisis and oil shortage, but also to make electric vehicles have gained vitality, to the 20th century, 80 years, with the people for air quality and greenhouse From the early 90 s of the 20th century, the world's major car companies such as Ford, GM, Nissan, Toyota and Honda and so on, have invested in the electric vehicle than in the early 20th century, Toyota's RAV4, Prius and FCEV, Honda's EVPlus, Insight and FCX-V3, etc. With the development of the national and domestic electric vehicles and electric vehicle concept cars, such as Ford's Think City, GM's EV1, Eleventh Five-Year Plan electric car major science and technology special launch, across the country also set off a research and development of electric car boom.

\section{The Problems and Shortcomings of Chinese Electric Vehicle}

Although the development of electric vehicles in China has made great progress, but there are some problems and shortcomings, these factors will restrict the development of electric vehicles in China.

First of all, the bottleneck restricting the development of China's electric vehicle technology needs a breakthrough. Development of electric vehicles must address several key technologies, such as batteries, motors and control technology. In China, the development of high-energy battery has just started and the current power battery than the low energy than the power is not enough, the charging time is too long, battery life and continued journey than the fuel-gas vehicle short. Also, almost all of Chinese automobile engine electronic controller is developed abroad. As for fuel cell vehicles, there is a need to address hydrogen fuel storage and transportation and other technical issues.

Second, the price of electric vehicles is too high to hinder the popularization and industrialization of electric vehicles. Electric cars are more expensive than ordinary fuel cars to hybrid cars, for example, the cost of this car is higher than the average car, the current subsidy of individual consumers, the electric car is clearly a lack of attractiveness And difficult to enter the market, there is no 
market cannot have the scale of production and industrialization, there is no scale cannot reduce costs and prices.

Finally, the development of electric vehicles in our supporting facilities is not perfect. To electric vehicles, for example, to solve the problem of charging stations for electric vehicles need to build charging stations, charging stations in China is currently very small, which gives the use of electric vehicles has brought great inconvenience. As for hydrogen fuel vehicles and hydrogen fuel cell vehicles, the construction of hydrogenation equipment and hydrogen refueling station is a huge capital investment, without the Government's promotion, the popularity of fuel cell vehicles will be difficult.

\section{The Key Technology of Electric Vehicles}

As the typical high-tech products, the ultimate goal of the electric vehicle is to realize the intelligent, digital and light weight. At present, the key of the research and development is the integration of the high-tech of the electric vehicle as the mechanical, electronic, energy, computer, automobile, information technology. Technology is mainly battery, motor, motor control, body and chassis design, as well as energy management technology, among which the first three is the development of electric vehicles bottleneck.

\subsection{Electric vehicle batteries}

(E), energy density (Ed), specific power $(\mathrm{P})$, cycle life $(\mathrm{L})$, battery life cycle (L), electric vehicle battery life cycle and cost $(\mathrm{C})$, etc. To make electric vehicles and fuel vehicles to compete, the key is to develop a specific energy than the power, long life and high efficiency battery.

\subsection{The motor and its control technology}

Motor and drive system is a key component of electric vehicles, electric vehicles to make good use of performance, drive motor should have a wide speed range, high speed, large starting torque, small size, high quality, high efficiency and dynamic system (PM), Permanent Magnet Brushless Motor (PMBLM) and Switched Reluctance Motor (SRM), the performance of electric motor (DCM), induction motor (IM), and their performance Contrast as shown in Table 2. In recent years, electric vehicles with DC motor to the development of alternating current, DC motor has basically been $\mathrm{AC}$ motor, permanent magnet motor or switched reluctance motor replaced.

Induction motor is also a kind of electric motor driven by electric vehicle. Its speed control technology is mature. It has the advantages of simple structure, small volume, low quality, low cost, reliable running, low torque ripple, low noise, V / F control, slip frequency control, vector control and direct torque control (DTC) .In the 20th century, 90 years ago, the main way to achieve the PWM V / F control And slip frequency control, but the speed control range is 
small, the torque characteristics are not ideal, it is not suitable for frequent start, frequent acceleration and deceleration of electric vehicles. In recent years, the induction motor-driven electric vehicles are almost all vector control and direct Torque control. Vector control and maximum efficiency control and speed vector control, the former is to make the excitation current with the motor parameters and load conditions change, so that the motor loss is minimal, the maximum efficiency; the latter is the use of motor voltage, Current and motor parameters to estimate the speed, without the speed sensor, so as to achieve a simplified system, reduce costs and improve the reliability of the purpose of direct torque control to overcome the vector control decoupling of the idea, the rotor flux orientation change for the stator magnetic The direct torque control method is direct, the structure is simple, the control performance is excellent, and the dynamic response is rapid, and the torque is controlled by the control of the stator flux linkage amplitude and the angle of the vector with respect to the rotor flux linkage., So very suitable for electric vehicle control. The United States and Europe developed electric vehicles to use this motor.

\section{The Development Trend Analysis of Chinese Electric Vehicle}

In China, compared with the other two new energy vehicles, pure electric vehicles, whether in technology or enterprise participation are more advantages, its zero emissions, zero pollution, environmental advantages and relative to other new energy vehicles in terms of price advantage But also more easily recognized by the public. This is mainly because the key technology in China's electric vehicle battery, motor development based on the pure electric vehicle R \& D is also less than Japan and South Korea, China's low-power lithium-ion battery has long been industrialization, the formation of upstream and downstream Combined with a complete industrial chain, the battery products more than onethird of the world market, lithium-ion battery technology has reached the international advanced level, the industrialization of the basic conditions are ripe, Shenzhen BYD lithium-ion battery technology is the international leader, Has achieved industrial production. China's high-power battery is also very rapid development, compared with foreign countries have great price advantage. In addition, China is a permanent magnet synchronous motor permanent magnet material - a large country of rare earth resources, rare earth reserves of the world's first will be conducive to the future to reduce the manufacturing cost of electric vehicles. Hybrid electric vehicle is China's current low-volume production, alternative fuel vehicles to reduce emissions of more realistic electric vehicles. The development of hybrid electric vehicles is also dependent on the development of power batteries, hybrid electric vehicles in its specific market within the scope of commercial production will continue to grow, the growth rate depends on the price factor. China's fuel cell vehicles in the vehicle handling performance, driving performance, safety performance, fuel efficiency reached the international advanced level, but at this stage, fuel cell vehicles because of its high cost, expensive and technical constraints, coupled with supporting The 
establishment of infrastructure such as hydrogen refueling stations and pipeline imperfections, so China's fuel cell vehicles in recent years, it is difficult to realize the true sense of the industrialization. At this point, our country and other countries are facing the same problem.

In short, from the long-term development trend, China's hybrid electric vehicles will have long-term market prospects. However, pure electric vehicles and fuel cell vehicles in the industrialization of the advantages may be greater. Although hybrid vehicles have better fuel economy and meet the requirements of high emission standards in the current high oil price period, hybrid vehicles can only be used as a transition route because they are only relative improvements to existing automobile technologies. The pure electric vehicles and hydrogen fuel cell vehicles in the use of the process to achieve zero emissions, and completely out of dependence on oil resources, will become the ultimate goal of the development of electric vehicles in China.

\section{Conclusion}

From the environmental point of view or from the energy point of view, the future electric vehicles need to have a big development, the development is related to the rise and fall of many industries and it may become a new economic growth point in the future. The government should encourage the development of electric vehicles according to the market mechanism, at the same time pay close attention to the charging station and other infrastructure construction, and in the policies and regulations to be supported. It can be expected that in the future, the car will be by the electrical, mechanical and control technology to run the vehicle. And only the development of clean, efficient, intelligent electric vehicles can make the 21 st century traffic sustainable development.

\section{References}

[1] Chan C C. The state of the art of electric and hybrid vehicles. Proceeding of IEEE, 55(12), pp.68-70, 2011

[2] Riazenman M J. Engineering the EV future. IEEE. Spectrum, 8 (5), pp.87- 91, 20013

[3] Hori Y. Future vehicle driven by electricity and control research on four wheel motored/UOT electric march. IEEE Advanced Motion Control, 12(10), pp. 18- 20, 2012

[4] Kashima S. The present condition and the future of EV-sharing in Japan. IEEE Vehicle Electronics Conference, 9(6), pp.58- 61, 2011

[5] McDowall J. Conventional battery technologies-present and future. IEEE Power Engineering Society Summer Meeting, 8(4), pp.85-87, 2014 